Gut, 1982 23, 14-20

\title{
Fractionation of the liver membrane lipoprotein (LSP) and characterisation of its antigenic determinants by autoantibodies and a heterologous anti-serum
}

\author{
M MANNS AND K-H MEYER ZUM BÜSCHENFELDE* \\ From the First Department of Internal Medicine and Policlinic, University of Mainz, Mainz, \\ Federal Republic of Germany
}

SUMMARY Sera from 50 patients with chronic active liver disease were investigated by radioimmunoprecipitation test for autoantibodies against human and rabbit liver membrane lipoprotein (LSP), and a human kidney equivalent protein. Twenty-one of 50 chronic active liver disease sera were positive for autoantibodies against human liver membrane lipoprotein. Eleven of 50 sera reacted with rabbit liver membrane lipoprotein and four of 50 sera with human kidney equivalent protein as well. In order to identify the antigenic determinants of these autoantibodies ${ }^{125}$ I-labelled human and rabbit liver membrane lipoprotein and human kidney equivalent protein were fractionated by $\mathrm{CsCl}$ density gradient centrifugation. Distribution of labelled antigen fractions in density gradients revealed two peaks with maximum radioactivity at 1.34 and $1.11 \mathrm{~g} / \mathrm{ml}$. Density gradient fractions were assayed for antigen activity by radioimmunoprecipitation test using autoantibody positive sera of patients with chronic active liver disease. Anti-human and anti-rabbit liver membrane lipoprotein and anti-human kidney equivalent protein positive human sera all localised their corresponding determinants in the low density fractions $(1.08-1.10 \mathrm{~g} / \mathrm{ml})$. An antiserum against human liver membrane lipoprotein, raised in rabbits after short-term immunisation, recognised the low density ${ }^{125}$ I-human liver membrane lipoprotein subfraction. This serum had previously been absorbed with human kidney homogenate, plasma, and blood cells. Thus, organ-specific and non-organ-specific determinants were both localised in the low density liver membrane lipoprotein subfraction. They could not be separated by the described fractionation procedure. It is to be supposed that organ-specific determinants of a low density membrane protein of hepatocytes are targets of circulating autoantibodies in chronic active liver disease.

In recent years a soluble macromolecular protein fraction from normal human liver has attracted the attention of hepatologists. It was originally prepared by homogenisation, differential ultracentrifugation, and gel filtration on Sephadex G 100. The concentrated first peak of Sephadex G 100 had been rechromatographed on Sephadex G 200. The concentrated first peak of Sephadex G 200 was used for the immunisation of animals. After the absorption of antisera with human kidney homogenate, human plasma, and blood cells, these antisera reacted only with the macromolecular protein fraction from the

*Address for correspondence: Professor Dr K-H Meyer zum Büschenfelde, 1. Medizinische Klinik und Poliklinik, Langenbeckstrasse 1, D-6500 Mainz, FRG.

Received for publication 23 June 1981 liver but not with equivalent protein fractions from other organs. ${ }^{1}$ Studies with antisera prepared in different species led to the conclusion that the macromolecular protein fraction contains a protein with an organ-specific determinant which was originally termed LP I. In later studies this determinant was found to be membrane associated. ${ }^{2}$ McFarlane et al. ${ }^{3}$ described a further purification of the LP I containing liver protein fraction by Sepharose 6 B chromatography. Since then the term liver specific membrane lipoprotein (LSP) has been used for this antigen preparation in literature.

Recently, circulating autoantibodies against the LSP antigen fraction were demonstrated in patient sera by radioimmunoprecipitation (RIP). These autoantibodies were frequently found in acute and 
chronic inflamatory liver diseases, irrespective of HBsAg status, and were associated with disease activity. ${ }^{4-7}$ In addition, cellular immune reactions against the LSP antigen fraction have been observed in acute and chronic inflammatory liver diseases. ${ }^{8-15}$ As the LSP preparation used in different immunological test systems contains different antigenic determinants, ${ }^{761718}$ it remains unclear whether or not autoantibodies in patient sera are directed against an identical molecule with organspecific or non-organ-specific determinants of the LSP fraction. Thus the aim of this study is a further fractionation of the LSP fraction to allow a better identification and characterisation of the antigenic determinants by autoantibodies and heterologous anti-LSP serum.

\section{Methods}

\section{ANTIGEN PREPARATION}

Human LSP, rabbit LSP, and the human kidney equivalent protein (HKP) were prepared according to McFarlane $e t a l^{3}$ Concentrated first peak of Sepharose $6 \mathrm{~B}$ was radiolabelled with ${ }^{125} \mathrm{I}$ using the chloramine $\mathrm{T}$ method. ${ }^{19}$ For detailed information see Kakumu et al. ${ }^{5}$ and Manns et al..$^{7}$ The specific activity of labelled antigen was approximately $60 \mathrm{mCi} / \mathrm{mg}$.

\section{DENSITY CENTRIFUGATION}

For further fractionation labelled LSP and HKP were submitted to ultracentrifugal flotation in a $\mathrm{CsCl}$ gradient. A gradient was established as follows; $\mathrm{CsCl}$ was dissolved in $0.01 \mathrm{M}$ Tris, $\mathrm{pH} 8$, containing $0.02 \mathrm{M} \mathrm{NaCl}, 0.1 \mathrm{M}$ EDTA, and $0.1 \% \mathrm{BSA}$ at densities of $1.28 \mathrm{~g} / \mathrm{ml}$ (solution 1$), 1.16 \mathrm{~g} / \mathrm{ml}$ (solution 2) $1.08 \mathrm{~g} / \mathrm{ml}$ (solution 3), and $1.04 \mathrm{~g} / \mathrm{ml}$ (solution 4). Densities were determined from their refractive indices by a Zeiss refractometer. The $\mathrm{CsCl}$ density gradient was prepared in $12 \mathrm{ml}$ tubes by sequentially overlaying $4.0 \mathrm{ml}$ of solution 1 , containing $6 \mu \mathrm{g}$ of labelled antigen protein, $4.5 \mathrm{ml}$ of solution $2,2.5 \mathrm{ml}$ of solution 3 , and $1.0 \mathrm{ml}$ of solution 4 . Tubes were centrifuged in a Beckman SW 41 rotor at $30000 \mathrm{rpm}$ for 24 hours. After centrifugation fractions were taken by bottom puncture of the tubes and measured for density and radioactivity. Antigen activity of density gradient fractions was tested by RIP after labelled LSP or HKP had been fractionated.

\section{SERA}

Sera were obtained from patients with liver diseases, and diagnoses were confirmed by liver biopsy. Control sera were obtained from healthy blood donors who had no clinical or laboratory signs of liver diseases including negative $\mathrm{B}$ virus serology. Rabbit anti- human LSP serum was produced by short-term immunisation as described elsewhere. ${ }^{17}$ Heat inactivated rabbit serum was absorbed twice with equal volumes of human kidney homogenate and $25 \mathrm{mg}$ lyophilised human plasma protein per $\mathrm{ml}$ serum for 30 minutes at $37^{\circ} \mathrm{C}$ and then 16 hours at $4^{\circ} \mathrm{C}$. The incubates were centrifuged for 10 minutes at $50000 \mathrm{~g}$ in a Sorvall RCZ-B centrifuge.

\section{RADIOIMMUNOPRECIPITATION TEST WITH HUMAN ANTI-LSP ANTOANTIBODIES}

Patients' sera were tested for anti-LSP autoantibodies by RIP according to Manns et al. ${ }^{7}$ This test is similar to the one described by Kakumu et al. ${ }^{5}$

The different gradient fractions of labelled LSP or HKP were assayed for antigenic activity by RIP as follows: fractions of the $\mathrm{CsCl}$ gradient were diluted in Tris/EDTA buffer, $\mathrm{pH} 8$, containing $0.25 \%$ BSA to $32000 \mathrm{cpm} .100 \mu \mathrm{g}$ of antigen protein $(32000 \mathrm{cpm})$, approximately $1 \mu \mathrm{g}$ protein, were incubated with $50 \mu \mathrm{l}$ of serum from patients with chronic active liver disease (dilution 1:10). These were positive for antiLSP autoantibody as tested by RIP according to Manns et al. ${ }^{7}$ using concentrated Sepharose 6 B first peak as labelled antigen. After the addition of another $500 \mu$ l of Tris/EDTA buffer, containing $0.25 \%$ BSA the mixture was left at $4^{\circ} \mathrm{C}$ for 72 hours. Then $100 \mu \mathrm{l}$ anti human IgG produced in rabbits (Hyland Travenol Laboratories, Munich, Germany), diluted to give optimal precipitation, were added as a second antibody. After 48 hours at $4^{\circ} \mathrm{C}$ tubes were centrifuged and precipitants were counted in a Beckman gamma counter. All fractions were tested within the same assay procedure with a serum pool from healthy blood donors instead of anti-LSP autoantibody serum as first antibody. Each fraction was tested twice. Results are expressed as positive/negative ratio $(\mathrm{P} / \mathrm{N})$. This means that the counts per minute precipitated by a test serum were compared with the counts per minute precipitated by the normal human serum pool within the same assay procedure. A P/N ratio exceeding $2 \cdot 1$ was regarded as positive. Specific activity precipitated was $15-25 \%$.

\section{RADIOIMMUNOPRECIPITATION TEST}

WITH HUMAN ANTI-LSP AUTOANTIBODIES

Different fractions of the $\mathrm{CsCl}$ gradient were assayed for antigen activity by rabbit anti-human LSP serum previously absorbed twice with human kidney homogenate and human plasma. $\mathrm{CsCl}$ density fractions were diluted with Tris/EDTA buffer to $16000 \mathrm{cpm} / 100 \mu \mathrm{l}$. One hundred microlitres of labelled antigen were incubated with $50 \mu \mathrm{l}$ of heterologous anti LSP serum diluted 1:100 and $500 \mu \mathrm{l}$ Tris/EDTA containing $0.25 \%$ BSA. After 72 hours at 
$4^{\circ} \mathrm{C} 100 \mu \mathrm{l}$ of anti-rabbit IgG raised in goats, diluted and thus giving optimal precipitation (Behring Werke, Marburg, Germany), were added. After 48 hours at $4^{\circ} \mathrm{C}$ tubes were centrifuged and precipitants were counted in a Beckman gamma counter. All fractions were assayed in the same procedure by rabbit preserum 1:10 instead of heterologous anti-LSP serum as first antibody. Anti-LSP serum and preserum were tested in two independent experiments. Means were taken to calculate results as percentage cpm precipitated:

Percentage CPM precipitated:

(cpm rabbit anti-LSP serum-cpm preserum) $\times 100$

(cpm supernatant + precipitant)-cpm preserum

\section{Results}

\section{AUTOANTIBODIES AGAINST LSP}

ANTIGEN FRACTION

Fifty sera from patients with chronic active liver disease (CALD) were tested for autoantibodies against human LSP, rabbit LSP, and HKP. The antigen fractions were prepared according to McFarlane et al. $^{3}$ Autoantibodies against these antigen preparations were determined by RIP. ${ }^{7}$ Twenty-one of 50 sera were positive for anti-human LSP. The 29 sera, negative for anti-human LSP, were negative for anti-rabbit LSP and anti-HKP as well. From the 21 anti-human LSP positive sera 11 reacted with rabbit LSP and four with HKP. There was no correlation between autoantibody positive sera and HBsAg status (Table).

Table Autoantiblodies against LSP antigen fraction on sera from patients with chronic active liver disease

\begin{tabular}{llll}
\hline & Anti-HLSP & Anti-RLSP & Anti-HKP \\
\hline HBsAg positive & $10 / 26$ & $5 / 26$ & $3 / 26$ \\
HBsAg positive & $11 / 24$ & $6 / 24$ & $1 / 24$ \\
Total & $21 / 50$ & $11 / 50$ & $4 / 50$ \\
\hline
\end{tabular}

HLSP: human liver specific protein.

RLSP: rabbit liver specific protein.

HKP: human kidney equivalent protein.

HBsAg: hepatitis B virus surface antigen.

\section{DISTRIBUTION OF LABELLED ANTIGENS IN} CsCI DENSITY GRADIENTS

Human LSP, rabbit LSP, and HKP were labelled with ${ }^{125}$ Iodine using the chloramine $\mathrm{T}^{19}$ method and submitted to ultracentrifugal flotation in $\mathrm{CsCl}$ density gradient as described in materials and methods. Radioactivity (CPM) is distributed in two peaks with maximum radioactivity at densities $1.32-1.34$ and $1 \cdot 11-1.14 \mathrm{~g} / \mathrm{ml}$. A similar distribution pattern was obtained for human, and rabbit LSP fraction as well as for HKP. Results obtained for human LSP fraction and HKP are shown in Fig. 1.

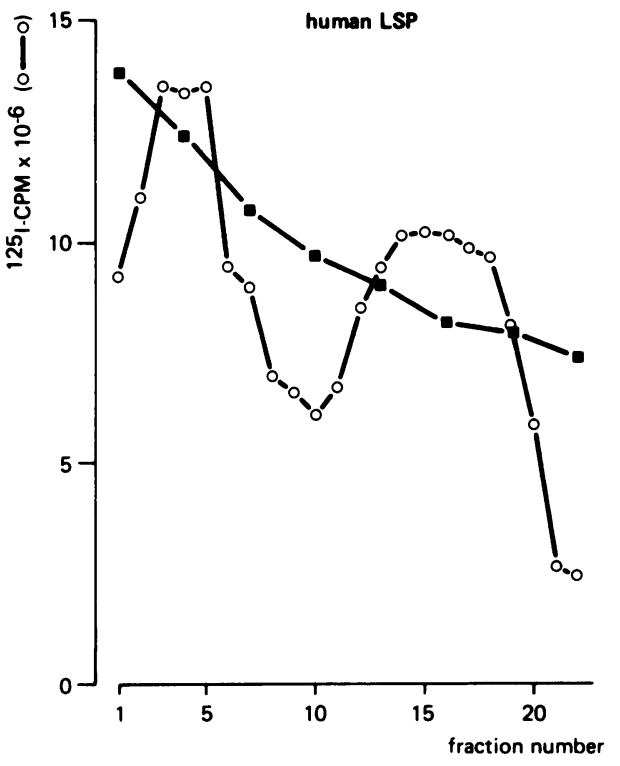

A

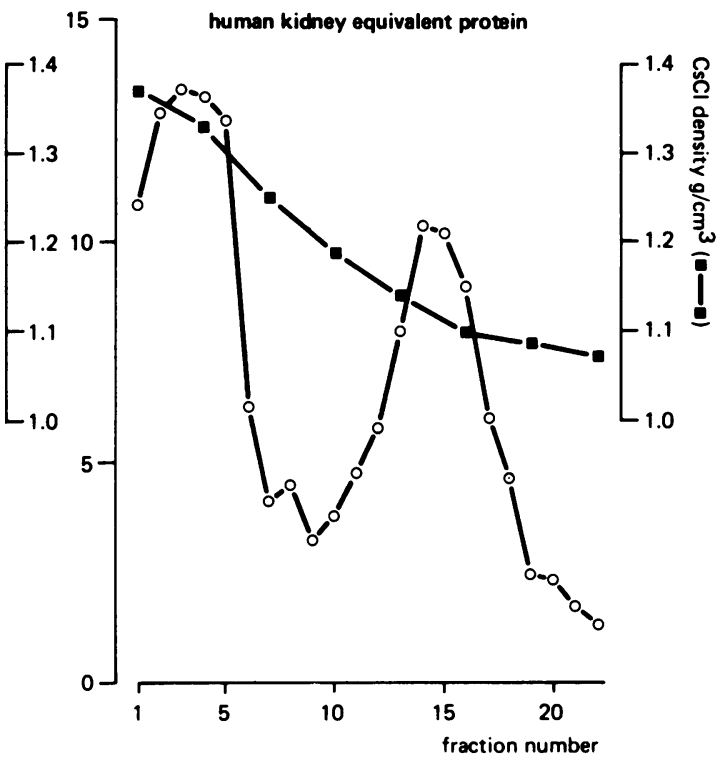

B

Fig. 1 Six $\mu g$ of labelled human liver specific protein $(A)$ or the kidney equivalent protein (B) were submitted to ultracentrifugal flotation in a discontinuous $\mathrm{CsCl}$ gradient. Both labelled antigen preparations distributed in two peaks with maximum activities at 1.34 and $1.11 \mathrm{~g} / \mathrm{ml}$. 
The different density gradient fractions were applied to SDS polyacrylamide gel electrophoresis. Gel columns were subdivided in 85 slices by gel slicer and individual slices were counted for radioactivity. Results obtained for different gradient fractions are shown in Fig. 2.

\section{DENSITY GRADIENT FRACTIONS ASSAYED \\ FOR ANTIGEN ACTIVITY BY \\ RADIOIMMUNOPRECIPITATION WITH \\ SERA POSITIVE FOR AUTOANTIBODIES \\ AGAINST HUMAN LSP FRACTION}

Individual fractions of $\mathrm{CsCl}$ density gradients were tested by RIP using autoantibodies against human LSP fraction from patients with chronic active liver disease. Maximum antigen activity was found in the low density fraction $(1.08-1 \cdot 10 \mathrm{~g} / \mathrm{ml})$ for all sera tested, indicating that the relevant target antigen is of lipoprotein nature. Results of three representative sera are given in Fig. 2A. The four chronic active liver disease sera reacting with HKP (Table) reacted with the low density fractions of $\mathrm{CsCl}$ density gradient of HKP as well. Figure 2B shows one representative antiHKP positive serum and two sera that reacted neither with $\mathrm{HKP}$ nor with fractions of $\mathrm{CsCl}$ density gradient of labelled HKP but with the low density fractions of human LSP. Thus organ-specific and non-organspecific determinants of the LSP fraction were both localised in the low density fractions of $\mathrm{CsCl}$ density gradient.

\section{DENSITY GRADIENT FRACTIONS OF HUMAN LSP TESTED BY \\ RADIOIMMUNOPRECIPITATION WITH HETEROLOGOUS ANTI-HUMAN LSP SERUM}

Rabbit anti-human LSP serum previously absorbed with human kidney homogenate and human plasma recognised the low density ${ }^{125}$ I-LSP subfraction when

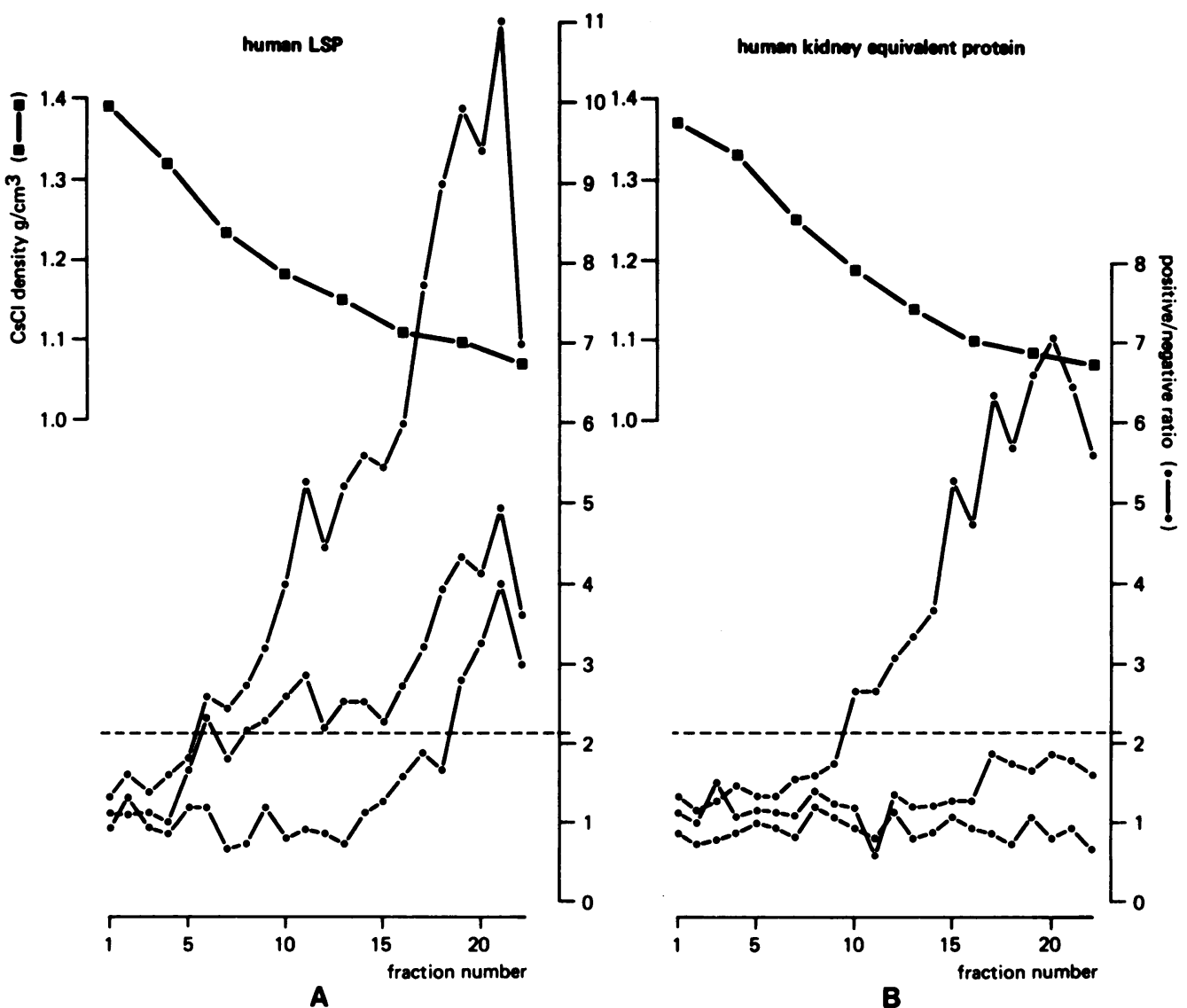

Fig. 2 Localisation of antigen activity in density gradient fractions by radioimmunoprecipitation (RIP) with anti-LSP autoantibodies. Dotted line: upper limit of normal range. A: CsCl density grandient of ${ }^{125}$ I liver specific protein. $B$ : CsCl density gradient of ${ }^{125}$ I human kidney equivalent protein. 


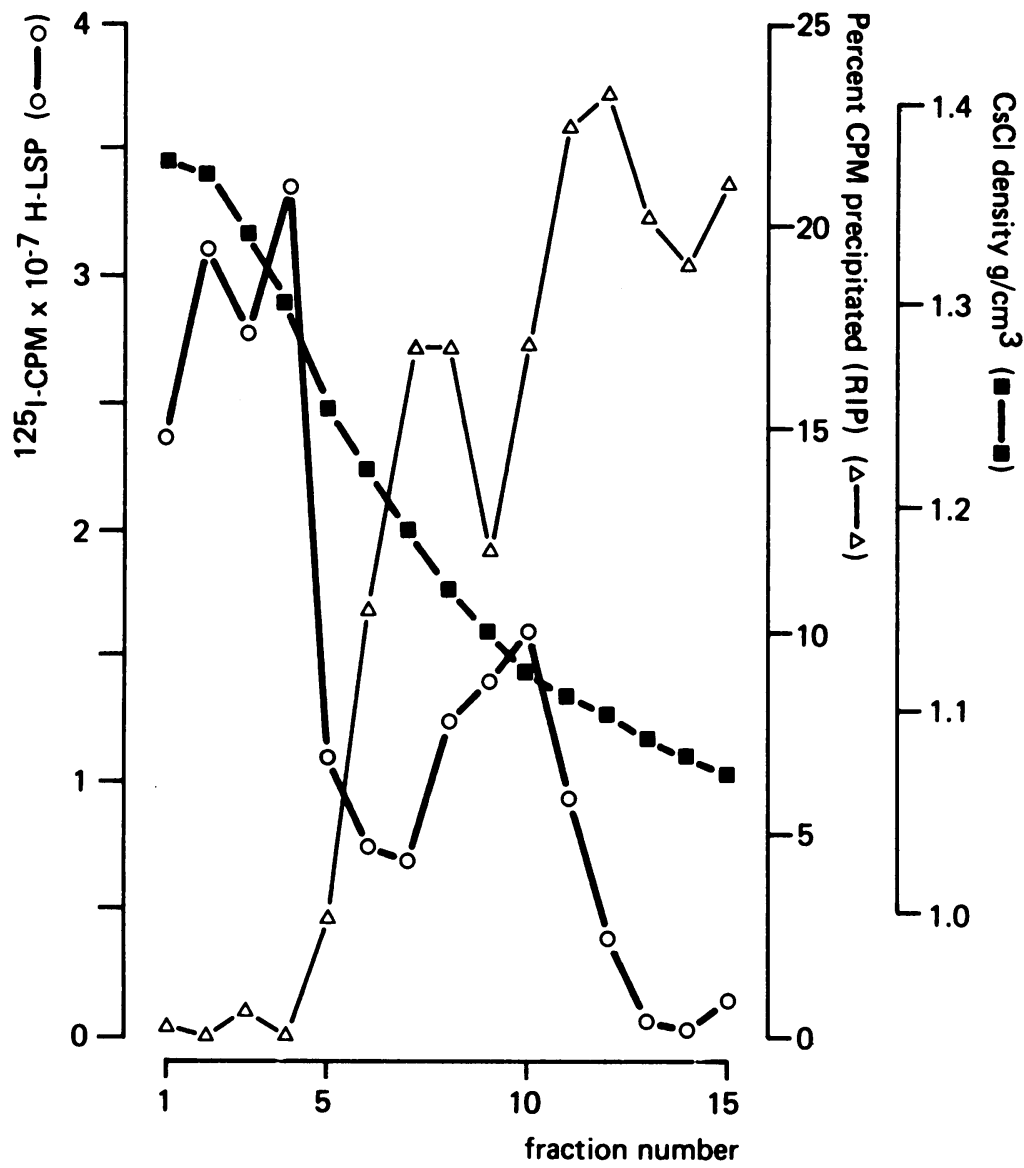

Fig. 3 Localisation of LSP activity in $\mathrm{CsCl}$ density gradient by radioimmunoprecipitation (RIP) with anti-human LSP serum prepared in rabbit. The antiserum was previously absorbed with kidney homogenate, plasma, and blood cells. tested by radioimmunoprecipitation test (Fig. 3). Negative results were obtained with LSP preparations from other species. Absorption of antiserum was proved by testing density gradient fractions of 125I-HKP under equivalent conditions. All these studies gave negative results. Thus absorbed rabbit anti-human LSP serum obtained after short-term immunisation recognises a species- and organ-specific determinant which is localised in the low density subfraction of the human LSP preparation.

\section{Discussion}

At present investigations on humoral and cellmediated immune reactions are performed with the whole LSP fraction as antigen. These antigen fractions are prepared by the technique described by McFarlane et $a l .{ }^{3}$ In order to define and identify antigenic determinants within the LSP fraction, human LSP, rabbit LSP, and HKP were fractionated by density gradient centrifugation. All fractions were tested by radioimmunoprecipitation test using autoantibodies of sera from patients. with chronic active liver disease and absorbed rabbit anti-human LSP serum.

The 21 sera containing anti-human LSP autoantibodies (Table) recognised only a low density ${ }^{125} \mathrm{I}$-human-LSP-subfraction $(1.08-1 \cdot 10 \mathrm{~g} / \mathrm{ml})$ obtained after $\mathrm{CsCl}$ density gradient centrifugation. Labelled rabbit LSP and HKP were also submitted to $\mathrm{CsCl}$ density gradient centrifugation. The distribution of ${ }^{125} \mathrm{I}$-rabbit LSP and ${ }^{125} \mathrm{I}-\mathrm{HKP}$ in $\mathrm{CsCl}$ density gradients was similar when compared with human LSP. The 11 sera positive for anti-rabbit LSP and the four anti-HKP positive sera reacted with the low density subfraction of rabbit LSP and HKP, respectively. Thus autoantibodies in sera from patients with chronic active liver disease predominantly react with organ-specific determinants of LSP fractions of different species. Only four of 21 antihuman LSP positive sera reacted with non-organspecific determinants of the low density LSP subfraction. It can be concluded from these data that 
species-specific and non-species-specific determinants of a low density protein are targets for autoantibodies in human inflammatory liver diseases.

Heterologous anti-LSP serum, originally used to identify the organ-specific determinant, reacted with the low density gradient fractions of human LSP as well. This serum, obtained after short-term immunisation, detects an organ- and species-specific determinant, which is in accordance with previous investigations, when crossed immunoelectrophoresis was used to characterise heterologous anti-LSP sera. ${ }^{17}$ In this study, sera from rabbits with experimentally induced chronic hepatitis were shown to contain antiLSP antibodies reacting with non-species-specific determinants.

The techniques used so far have been unable physically to separate the organ-specific and nonorgan-specific determinants. The possibility that organ-specific and non-organ-specific determinants are both located on an identical molecule of a lipoprotein nature should be considered. Further studies are needed to clarify whether or not antibodies in patients' sera and heteroimmune sera are partially directed against identical determinants. Recently DeKretser et al. ${ }^{20}$ demonstrated the membraneassociation of an LSP determinant which was recognised by absorbed heterologous anti-serum and autoantibodies. In immunodiffusion studies guineapig anti-LSP serum and sera from patients with $\mathrm{HBsAg}$ positive and negative chronic active hepatitis reacted with one precipitin line with total rabbit LSP fraction and a plasma membrane fraction isolated from normal rabbit liver. These studies confirm the membrane association of a liver-specific determinant and give evidence that autoantibodies are directed against at least one organ-specific determinant detected by heteroimmune sera.

The data that are presented describe a low density liver protein fraction as target antigen of human autoantibodies in chronic active liver disease. This protein fraction bears a liver specific determinant detected by human autoantibodies and absorbed heterologous antiserum.

Although, in addition to our studies, biochemical and immunochemical characterisation of the low density liver protein fraction may be necessary, it has become less speculative that an organ-specific determinant of the liver cell membrane is involved in immune processes of human inflammatory liver diseases. Nevertheless, it has to be proved whether there is, in fact, a causal link between the described immune phenomena and hepatocellular injury.

We thank Miss U Dang for excellent technical assistance. This work was supported by the Deutsche Forschungsgemeinschaft Me 244/13. Some of these data have been presented at the 15 th meeting of the European Association for the Study of the Liver (EASL), 4-6 September 1980, Belgrade, Yugoslavia.

\section{References}

${ }^{1}$ Meyer zum Büschenfelde KH, Miescher PA. Liver-specific antigens. Purification and characterization. Clin Exp Immunol 1972; 10:89-102.

${ }^{2}$ Hopf U, Meyer zum Büschenfelde KH, Freudenberg J. Liver-specific antigens of different species. II. Localization of a membrane antigen at cell surface of isolated hepatocytes. Clin Exp Immunol 1974; 16:117-23.

${ }^{3}$ McFarlane IG, Wojcicka BM, Zucker GM, Eddleston ALWF, Williams R. Purification and characterization of human liver-specific membrane lipoprotein (LSP). Clin Exp Immunol 1977; 27:381-90.

4Jensen DM, McFarlane IG, Portman BS, Eddleston ALWF, Williams R. Detection of antibodies directed against a liver-specific membrane lipoprotein in patients with acute and chronic active hepatitis. $N$ Engl J Med 1978; 299:1-7.

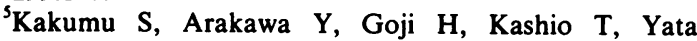
K.Occurrence and significance of antibody to liver-specific membrane lipoprotein by double-antibody immunoprecipitation method in sera of patients with acute and chronic liver disease. Gastroenterology 1979; 76:665-72.

${ }^{6}$ Gerber MA, Lebwohl N, Thung SN, Bodenheimer H, Schaffner F. Antibodies to liver specific membrane protein in liver and kidney disease. (Abstract). Gastroenterology 1979; 76:1281.

${ }^{7}$ Manns M, Meyer zum Büschenfelde KH, Hess G. Autoantibodies against liver specific protein: studies on disease-, species- and organ-specificity. Gut 1980; 21:955-61.

${ }^{8}$ Miller J, Smith MGM, Mitchell CG, Reed WD, Eddleston ALWF, Williams R. Cell mediated immunity to a human liver-specific antigen in patients with active chronic hepatitis and primary biliary cirrhosis. Lancet 1972; 2:296-7.

${ }^{9}$ Knolle J, Meyer zum Büschenfelde KH, Bolte JP, Berger J, Zelluläre Immunreaktionen gegenüber dem Hepatitisassoziierten Antigen (HAA) und homologem leberspezifischen Protein (HLP) bei akuten HAA-positiven Hepatitiden. Klin Wschr 1973; 51:1172-4.

${ }^{10}$ Meyer zum Büschenfelde KH, Knolle J, Berger J.Celluläre Immunreaktionen gegenüber homologen leberspezifischen Antigenen (HLP) bei chronischen Leberentzündungen. Klin Wschr 1974; 52:246-8.

${ }^{11}$ Thestrup-Pedersen K, Ladefoged K, Andersen P. Lymphocyte transformation test with liver-specific protein and phyto-haemagglutinin in patients with liver disease. Clin Exp Immunol 1976: 24:1-8.

${ }^{12}$ Vogten AJM, Hadzic N, Shorter RG, Summerskill WHJ, Taylor WF. Cell-mediated cytotoxicity in chronic active liver disease: a new test system. Gastroenterology 1978; 74:881-9.

${ }^{13}$ Thomson AD, Cochrane AMG, McFarlane IG, Eddleston ALWF, Williams R. Lymphocyte cytotoxicity to isolated hepatocytes in chronic active hepatitis. Nature 1974; 252:721-2. 
${ }^{14}$ Cochrane AMG, Moussouros A, Thomson AD, Eddleston ALWF, Williams R. Antibody-dependent, cell-mediated (K-cell) cytotoxicity against isolated rabbit hepatocytes in chronic active hepatitis. Lancet 1976 1:441-4.

${ }^{15}$ Cochrane AMG, Moussouros A, Smith A, Portman B, 'Eddleston ALWF, Williams R. Lymphocyte cytotoxicity in chronic active hepatitis: effect of therapy and correlations with clinical and histological changes. Gut 1978; 19:308-14.

${ }^{10}$ Behrens UJ, Paronetto F. Studies on liver-specific antigens. I. Evaluation of the liver specificity of LSP and LP-2. Gastroenterology 1979; 77:1045-52.

${ }^{17}$ Manns M, Meyer zum Büschenfelde KH, Hütteroth TH,
Hopf U. The liver specific protein: Evidence for speciesspecific and non-species specific determinants. J Clin Lab Immunol 1980; 3:9-13.

${ }^{18}$ McFarlane IG, Eddleston ALWF, Williams R. Liver specific protein-how specific? (Letter). Gastroenterology 1980; 78:1662.

${ }^{19}$ Hunter WM, Greenwood FC. Preparation of Iodine-131 labelled human growth hormone of high specific activity. Nature 1962; 191:495-6.

${ }^{20}$ DeKretser TA, McFarlane IG, Eddleston ALWF, Williams R. A species-non-specific liver plasma-membrane antigen and its involvement in chronic active hepatitis. Biochem $J$ 1980; 186:678-85. 